\title{
Preparation and properties of tristrontium aluminate as an alternative component of mineral trioxide aggregate (MTA) cement
}

\author{
Sherif ADEL ${ }^{1,2}$, Takahiro WADA ${ }^{3}$, Nobuyuki KAWASHIMA ${ }^{1}$, Ahmed ABDOU ${ }^{4,5}$, Hiroshi WATANABE ${ }^{6}$, \\ Tohru KURABAYASHI ${ }^{6}$, Takashi OKIJI ${ }^{1}$ and Motohiro UO $\mathrm{O}^{3,7}$ \\ ${ }^{1}$ Department of Pulp Biology and Endodontics, Graduate School of Medical and Dental Sciences, Tokyo Medical and Dental University, 1-5-45 \\ Yushima, Bunkyo-ku, Tokyo 113-8549, Japan \\ ${ }^{2}$ Department of Restorative and Dental Materials, Oral and Dental research division, National Research Centre of Egypt, El Buhouth street, Dokki, \\ 12622 Cairo, Egypt \\ ${ }^{3}$ Department of Advanced Biomaterials, Graduate School of Medical and Dental Sciences, Tokyo Medical and Dental University, 1-5-45 Yushima, \\ Bunkyo-ku, Tokyo 113-8549, Japan \\ ${ }^{4}$ Department of Cariology and Operative Dentistry, Graduate School of Medical and Dental Sciences, Tokyo Medical and Dental University, 1-5-45 \\ Yushima, Bunkyo-ku, Tokyo 113-8549, Japan \\ ${ }^{5}$ Department of Biomaterials, Faculty of Oral and Dental Medicine, Modern University for Technology and Information, El-hadaba El-Wosta, Mokatam, \\ 5th district, 11571 Cairo, Egypt \\ ${ }^{6}$ Department of Oral and Maxillofacial Radiology, Graduate School of Medical and Dental Sciences, Tokyo Medical and Dental University, 1-5-45 \\ Yushima, Bunkyo-ku, Tokyo 113-8549, Japan \\ ${ }^{7}$ Department of Materials Engineering, Graduate School of Engineering, The University of Tokyo, 7-3-1, Hongo, Bunkyo-ku, Tokyo 113-8656, \\ Japan \\ Corresponding author, Takahiro WADA; E-mail: wada.abm@tmd.ac.jp
}

This study evaluated tristrontium aluminate $\left(\mathrm{S}_{3} \mathrm{~A}\right)$ and its viability as a component for tricalcium silicate $\left(\mathrm{C}_{3} \mathrm{~S}\right)$ cements. The properties of $\mathrm{S}_{3} \mathrm{~A}, \mathrm{C}_{3} \mathrm{~S}$, and $\mathrm{S}_{3} \mathrm{~A} / \mathrm{C}_{3} \mathrm{~S}$ mixtures were evaluated in terms of setting time, compressive strength, flowability, and radiopacity. $\mathrm{X}$-ray diffraction (XRD) pattern verified the powder synthesized in the laboratory as $\mathrm{S}_{3} \mathrm{~A}$, consequently, confirming the preparation method. $\mathrm{S}_{3} \mathrm{~A}$ exhibited the lowest setting time, followed by $\mathrm{C}_{3} \mathrm{~S}$ and $\mathrm{S}_{3} \mathrm{~A} / \mathrm{C}_{3} \mathrm{~S}$ mixtures. Compressive strength of $\mathrm{C}_{3} \mathrm{~S}$ was significantly higher than $\mathrm{S}_{3} \mathrm{~A}$. The $\mathrm{S}_{3} \mathrm{~A} / \mathrm{C}_{3} \mathrm{~S}$ mixture showed comparable compressive strength to $\mathrm{C}_{3} \mathrm{~S}$ for 1-day post initial mixing. There was no significant difference in flowability between $\mathrm{S}_{3} \mathrm{~A} / \mathrm{C}_{3} \mathrm{~S}$ and mineral trioxide aggregate (MTA). $\mathrm{S}_{3} \mathrm{~A}$ showed comparable radiopacity to MTA, whereas that of the $\mathrm{S}_{3} \mathrm{~A} / \mathrm{C}_{3} \mathrm{~S}$ mixture was significantly lower comparatively; however, it achieved sufficient radiopacity (3 mm aluminum thickness equivalent). Further studies are needed to improve the manufacturing process of $\mathrm{S}_{3} \mathrm{~A}$ and evaluate the bioactive effect of strontium.

Keywords: Strontium aluminate, Mineral trioxide aggregate, Compressive strength, Flowability, Radiopacity

\section{INTRODUCTION}

Mineral trioxide aggregate (MTA) was introduced in the early nineties as a retrograde filling material, which could also be employed for fixing perforation ${ }^{1,2}$. MTA is composed primarily of Portland cement, which is the main ingredient of mortar and concrete; further, it contains tricalcium silicate, dicalcium silicate, tricalcium aluminate, and a small amount of tetracalcium aluminoferrite ${ }^{3,4}$. Moreover, bismuth oxide forms approximately $20 \%$ of the composition of MTA and acts as a radiopacifier ${ }^{4}$. MTA rapidly gained popularity as it established itself for its sealing ability ${ }^{5}$, biocompatibility ${ }^{6,7)}$, and antibacterial activity ${ }^{8,9)}$. MTA showed a remarkable capacity to induce hard tissue formation in an exposed pulp ${ }^{10-12}$. Thus, the scope of application of MTA gradually expanded to include apexification, pulpotomy, and pulp capping ${ }^{13)}$. Grey MTA was the first to be introduced as having the aforementioned composition, whereas white MTA was later introduced for esthetic applications; this was due to its purified composition that comprised a reduced iron oxide content, which was deemed as the cause of MTA's grey color ${ }^{3)}$. Several drawbacks of MTA were observed, including poor handling properties ${ }^{14)}$ and long setting time ${ }^{1)}$; these were of concern due to the ease with which the cement was washed out during placement. One of the reasons for the long setting time was the presence of bismuth oxide, which was shown to increase porosity and decrease compressive strength of the cement ${ }^{15}$. Bismuth oxide was also responsible for tooth discoloration in the use of both grey and white MTA ${ }^{16,177}$.

Tricalcium silicate $\left(3 \mathrm{CaO} \cdot \mathrm{SiO}_{2} ; \mathrm{C}_{3} \mathrm{~S}\right)$ was found to be the main active ingredient in Portland cement, as it composes roughly $52 \%$ of $\mathrm{MTA}^{18}$. Novel $\mathrm{C}_{3} \mathrm{~S}$-based dental repair cements may prove to be more favorable than Portland cement-based materials as $\mathrm{C}_{3} \mathrm{~S}$ exhibits a higher purity and does not contain trace elements ${ }^{19}$. Pure $\mathrm{C}_{3} \mathrm{~S}$ was shown to have sufficient biocompatibility and hard tissue promoting ability ${ }^{19,20)}$; further, it exhibits a shorter setting time than $\mathrm{MTA}^{21)}$. However, $\mathrm{C}_{3} \mathrm{~S}$ cement did not have sufficient radiopacity ${ }^{21}$.

Strontium ( $\mathrm{Sr}$ ) is an alkaline earth element similar to calcium $(\mathrm{Ca})$ and is naturally found in bone and teeth at a concentration of one hundred to several hundred parts per million (ppm). The effects of improving acid 
resistance and remineralization by incorporating $\mathrm{Sr}$ in teeth has been reported ${ }^{22-25)}$. Uo and Wada suggested that the above effects of Sr were related to the rapid incorporation into teeth from the surrounding fluid; this newly added Sr was found to exist in the Ca site of hydroxyapatite ${ }^{26,27)}$. Furthermore, strontium ranelate is available commercially as an osteoporosis treatment and its effectiveness as a pulp capping material to induce remineralization in an exposed rat dental pulp was also reported ${ }^{28}$. In addition, Sr was shown to effectively enhance the radiopacity of glass ionomer cements ${ }^{29}$.

On the other hand, tristrontium aluminate $\left(3 \mathrm{SrO} \cdot \mathrm{Al}_{2} \mathrm{O}_{3} ; \quad \mathrm{S}_{3} \mathrm{~A}\right)$ is well-known as one of the components of industrial cement and shows similar hydration and setting behaviors as those of $\mathrm{C}_{3} \mathrm{~S}$ and other major components of MTA cement ${ }^{30)}$. Therefore, $\mathrm{S}_{3} \mathrm{~A}$ is a potential material that can be utilized as a component of the MTA cement in order to improve the remineralization and enhance the radiopacity without adding bismuth oxide.

The aim of this study was to synthesize $\mathrm{S}_{3} \mathrm{~A}$ as a cement component to provide sufficient radiopacity; further, an investigation was carried out to elucidate the properties of the $\mathrm{S}_{3} \mathrm{~A}$ and its mixture with $\mathrm{C}_{3} \mathrm{~S}$, which is the major ingredient of MTA. This investigation was performed in terms of setting time, compressive strength, relative flowability, and radiopacity. We hypothesized that adding the $\mathrm{S}_{3} \mathrm{~A}$ component to $\mathrm{C}_{3} \mathrm{~S}$ cement will improve its radiopacity without negatively affecting the setting time, compressive strength, and relative flowability.

\section{MATERIALS AND METHODS}

\section{Preparation of $S_{3} A$ and experimental cements}

$\mathrm{S}_{3} \mathrm{~A}$ cement was prepared from strontium hydroxide octahydrate $\left(\mathrm{Sr}(\mathrm{OH})_{2} \bullet 8 \mathrm{H}_{2} \mathrm{O}\right.$; Kanto Chemical, Tokyo, Japan) and aluminum hydroxide $\left(\mathrm{Al}(\mathrm{OH})_{3}\right.$; Kanto Chemical), which were mixed at a molar ratio of 3:2. The mixture was heated at $180^{\circ} \mathrm{C}$ for $2 \mathrm{~h}$ to evaporate the water of hydration, then ground in the agate mortar. Obtained powder was calcined at $1,200^{\circ} \mathrm{C}$ for 4 h. Then, the calcined powder was ground again in the agate mortar. The crystal phase of obtained powder was identified using an X-ray diffractometer (XRD, Miniflex, Rigaku, Tokyo, Japan) with a scanning speed of $2 \%$ min. Synthetic $\mathrm{C}_{3} \mathrm{~S}$ powder was provided by Nippon Shika Yakuhin (Shimonoseki, Japan) and used for the following experiments as is. The mixture of $\mathrm{S}_{3} \mathrm{~A}$ and $\mathrm{C}_{3} \mathrm{~S}\left(\mathrm{~S}_{3} \mathrm{~A} / \mathrm{C}_{3} \mathrm{~S}\right)$ was prepared by mixing aforementioned $\mathrm{S}_{3} \mathrm{~A}$ and $\mathrm{C}_{3} \mathrm{~S}$ powders at a 1:1 weight ratio. ProRoot MTA (Dentsply, Johnson City, TN, USA) was used as a commercial MTA product for comparison with the experimental cements. In this study, $\mathrm{S}_{3} \mathrm{~A}, \mathrm{C}_{3} \mathrm{~S}$, and $\mathrm{S}_{3} \mathrm{~A} / 3 \mathrm{C}_{3} \mathrm{~S}$ mixture cements were mixed with distilled water (DW) at water/powder (W/P) ratios of 0.6, 0.5, and 0.6, respectively. Those W/P ratios are the minimum values for each experimental cement to produce sufficient workability. MTA was mixed with DW at a W/P ratio of 0.33 as recommended by the manufacturer.

\section{Scanning electron microscopy (SEM) observation}

SEM observation was carried out for $\mathrm{S}_{3} \mathrm{~A}, \mathrm{C}_{3} \mathrm{~S}$, and MTA powders. In addition, the cured cements were observed after 1 day (d) and $28 \mathrm{~d}$ post initial mixing.

\section{Setting time evaluation}

Setting time was estimated according to ISO 9917-1; $2007^{31)}$. The mixed cement specimen was filled into a stainless-steel mold with inner dimensions of $8 \times 10$ $\mathrm{mm}$ and $5 \mathrm{~mm}$ height. Each specimen was given the indentation test using a Vicat needle ( $1 \mathrm{~mm}$ in diameter) and with $400 \mathrm{~g}$ of weight in a plastic container kept at $37 \pm 1^{\circ} \mathrm{C}$ and $>90 \%$ humidity. Indentations were repeated every $60 \mathrm{~s}$ until the needle failed to make a complete circular indentation in the cement. The setting time was calculated as the time taken from the mixing of cement to the time where the needle failed to create an indentation. Three replicates of each material were tested.

\section{Compressive strength evaluation}

The compressive strength was determined according to ISO 9917-1; 2007'1) specifications. The cement was mixed with DW with the corresponding W/P ratio and filled into a separable cylindrical stainless steel mold of $4 \mathrm{~mm}$ in diameter and $6 \mathrm{~mm}$ in height. After filling the mixture, both sides of the mold were covered by glass plates, then kept at $37^{\circ} \mathrm{C}$ and $100 \%$ humidity. The specimens were divided into two groups. One half was kept for $1 \mathrm{~d}$ and another was kept for $28 \mathrm{~d}$. Each specimen was carefully removed from the mold and its new dimensions (diameter and height) were measured using a screw micrometer (QuantuMike series 293, Mitutoyo, Kanagawa, Japan). The compressive strength of these specimens was evaluated using the universal testing machine (EZ-LX, Shimadzu, Kyoto, Japan) with a test speed of $0.75 \mathrm{~mm} / \mathrm{min}$. Five replicates of each material were tested.

\section{Relative flowability}

The relative flowability was estimated by using the specimen weight normalized spread area under compression using a previously reported method ${ }^{32}$. A total of $0.06 \mathrm{~g}$ of powder for each cement was mixed with DW at the corresponding water/powder ratio. The hydrated cement was placed on a glass slab using a plastic ring of $6 \mathrm{~mm}$ in diameter and $1 \mathrm{~mm}$ thickness. The weight of the cement was measured using a precision balance (AG245, Mettler Toledo, Greifensee, Switzerland). After removing the ring, a second glass slab was placed on top of the cement and a weight of $1 \mathrm{~kg}$ was applied for $60 \mathrm{~s}$ at room temperature $\left(24^{\circ} \mathrm{C}\right)$. After removal of the weight, the surface of the cement was scanned with a flatbed scanner at a resolution of 600 dots-per-inch (dpi) (ApeosPort-IV C3375, Fuji Xerox, Tokyo, Japan). Afterwards, the surface area of the spread cement was calculated using image analysis software (ImageJ, Ver.1.52K, National Institute of Health, Bethesda, MD, USA). The relative flowability was calculated according to the following equation: 


$$
\text { Relative Flowability }=\frac{\text { area }\left(\mathrm{mm}^{2}\right)}{\text { weight of paste }(\mathrm{g})}
$$

Five replicates of each material were tested.

\section{Radiopacity}

Radiopacity was estimated according to ISO 6876; $2012^{33)}$ specifications. The specimens were prepared by mixing each cement powder with the corresponding $\mathrm{W} / \mathrm{P}$ ratio, and then formed into a disk shape $(10 \mathrm{~mm}$ in diameter and $1 \mathrm{~mm}$ thickness) using a plastic mold. The specimens were placed on an X-ray imaging plate with an aluminum step wedge of varying thickness (1-10 $\mathrm{mm})$, and the X-ray was irradiated using dental X-ray equipment (MaxiX, Morita Corp., Kyoto, Japan) with the following conditions; a voltage of $70 \mathrm{kV}$, a current of $7 \mathrm{~mA}$, an exposure time of $0.63 \mathrm{~s}$, and $15 \mathrm{~cm}$ distance between the imaging plate and cone end. The radiographs were obtained with an imaging plate reader (Carestream CS 7600, Carestream Health Japan, Tokyo, Japan). The mean grey value (MGV) of the specimen was estimated using ImageJ and the aluminum (Al) thickness equivalent was estimated using the aluminum step wedge. Three replicates of each material were tested.

\section{Statistical analysis}

A two-way ANOVA test was used for compressive strength evaluation followed by multiple comparisons with Bonferroni correction. A one-way ANOVA was used to compare between tested groups for setting time, flowability, and radiopacity followed by a pairwise comparison with Tukey's HSD $(\alpha=0.05)$ (IBM SPSS Statistics for Windows, Version 23.0. IBM, Armonk, NY, USA).

\section{RESULTS}

XRD analysis of the synthesized $S_{3} A$ powder

The XRD pattern of the synthesized $\mathrm{S}_{3} \mathrm{~A}$ powder is shown in Fig. 1. All observed peaks could be ascribed to those of the tristrontium aluminate $\left(\mathrm{Sr}_{3} \mathrm{Al}_{2} \mathrm{O}_{6}\right.$ : powder diffraction database (PDF) \#5529) for the powders that calcined at temperatures higher than $1,200^{\circ} \mathrm{C}$. Conversely, the powder that calcined at $1,100^{\circ} \mathrm{C}$ showed small peaks assigned to strontium oxide (SrO: PDF \#9238) and also a small halo, which might be derived from the amorphous phase that remained around $28^{\circ} \mathrm{C}$. Thus, it was considered that calcination at a temperature higher than $1,200^{\circ} \mathrm{C}$ is necessary for the synthesis of $\mathrm{S}_{3} \mathrm{~A}$.

\section{Scanning electron microscopy (SEM) observation}

SEM images of $\mathrm{S}_{3} \mathrm{~A}, \mathrm{C}_{3} \mathrm{~S}$, and MTA powders (Fig. 2) show that $\mathrm{S}_{3} \mathrm{~A}$ primarily comprised crude particles larger than several tens of micrometers $(\mu \mathrm{m})$, which exhibited irregular shapes with rough surfaces. Additionally, small amounts of micro particles of a few micrometers were observed. $\mathrm{C}_{3} \mathrm{~S}$ comprised elongated spherical primary particles with a homogenous particle size of about $1 \mu \mathrm{m}$. A part of the particles formed aggregates from secondary particles of several to $20 \mu \mathrm{m}$ size. MTA particle size

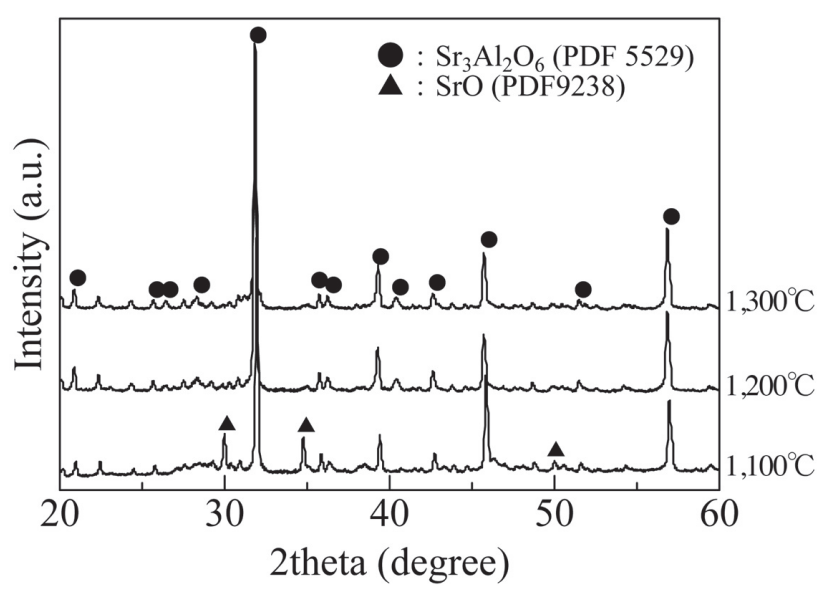

Fig. 1 XRD pattern of the strontium aluminate powders calcined at various temperatures.
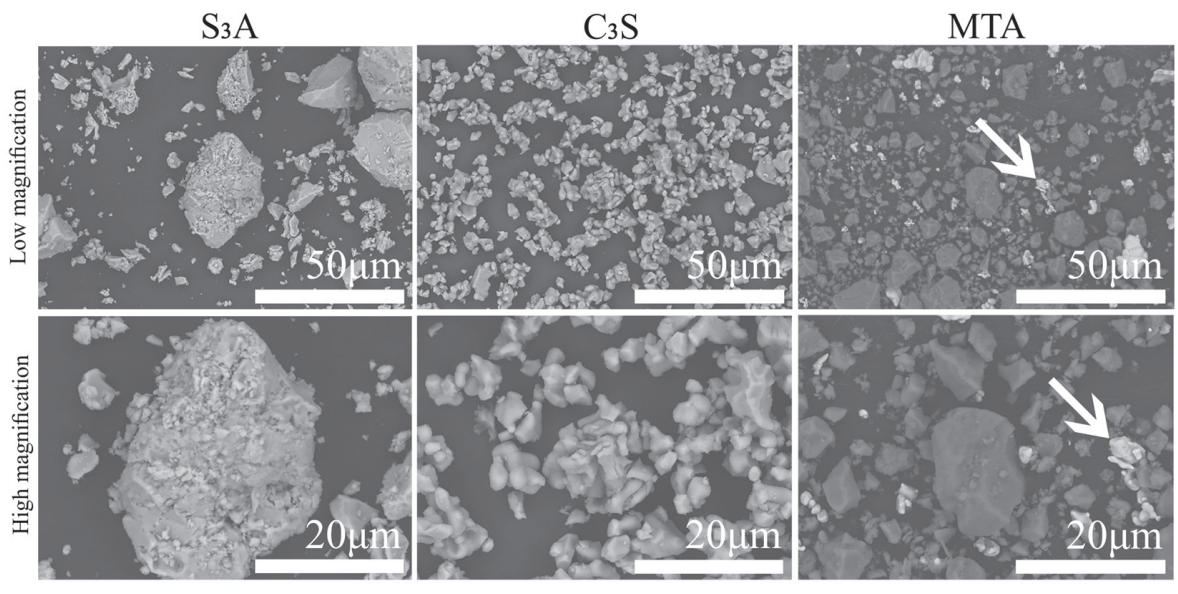

Fig. 2 SEM images of $\mathrm{S}_{3} \mathrm{~A}, \mathrm{C}_{3} \mathrm{~S}$, and MTA powders. 
was distributed from a few to $20 \mu \mathrm{m}$. The particle size distribution was homogenous in $\mathrm{C}_{3} \mathrm{~S}$, while $\mathrm{S}_{3} \mathrm{~A}$ showed the highest inhomogeneity with the widest range of particle sizes, followed by MTA. which showed moderate inhomogeneity. Furthermore, the radiopacifier of MTA appeared as white particles in the image (arrowed).

Figure 3 shows the SEM images of the cements at $1 \mathrm{~d}$ and $28 \mathrm{~d}$ after setting. The $\mathrm{S}_{3} \mathrm{~A}$ cement shows the needlelike precipitations at $1 \mathrm{~d}$ after setting. After $28 \mathrm{~d}$, the precipitate was increased but the shape was unaltered. In contrast, $\mathrm{C}_{3} \mathrm{~S}$ cement shows spherical aggregates after $1 \mathrm{~d}$ and the shape remained unchanged even after $28 \mathrm{~d}$. The shape of original MTA powder could be identified on $1 \mathrm{~d}$ after setting. After $28 \mathrm{~d}$, the gaps among the MTA resource powders were filled with small precipitations.

\section{Setting time}

Setting time results (Fig. 4) for the 3 groups were evaluated. $\mathrm{S}_{3} \mathrm{~A}$ (90.67 min (SD 3.79)) showed the lowest significant setting time followed by $\mathrm{C}_{3} \mathrm{~S}(152.67 \mathrm{~min}$ (SD 5.03)) and $\mathrm{S}_{3} \mathrm{~A} / \mathrm{C}_{3} \mathrm{~S}(299 \min (\mathrm{SD} \mathrm{1}))(p<0.001)$. Adding $\mathrm{S}_{3} \mathrm{~A}$ to $\mathrm{C}_{3} \mathrm{~S}$ at a $1: 1$ ratio increased setting time significantly.

\section{Compressive strength}

The compressive strength results were evaluated for the 3 groups $\left(\mathrm{S}_{3} \mathrm{~A}, \mathrm{C}_{3} \mathrm{~S}\right.$ and $\left.\mathrm{S}_{3} \mathrm{~A} / \mathrm{C}_{3} \mathrm{~S}\right)$ for $1 \mathrm{~d}$ and $28 \mathrm{~d}$ after mixing, which can be seen in Fig. 5. $\mathrm{C}_{3} \mathrm{~S}$ showed a significantly higher compressive strength compared to $\mathrm{S}_{3} \mathrm{~A}$ at both times. Adding $\mathrm{S}_{3} \mathrm{~A}$ to $\mathrm{C}_{3} \mathrm{~S}$ at a $1: 1$ ratio did not lower the compressive strength significantly as compared to $\mathrm{C}_{3} \mathrm{~S}$ on $1 \mathrm{~d}$; however, a significant decrease in compressive strength was observed after $28 \mathrm{~d}$. There was no significant increase in compressive strength between $1 \mathrm{~d}$ and after $28 \mathrm{~d}$ within each group except for $\mathrm{C}_{3} \mathrm{~S}$.
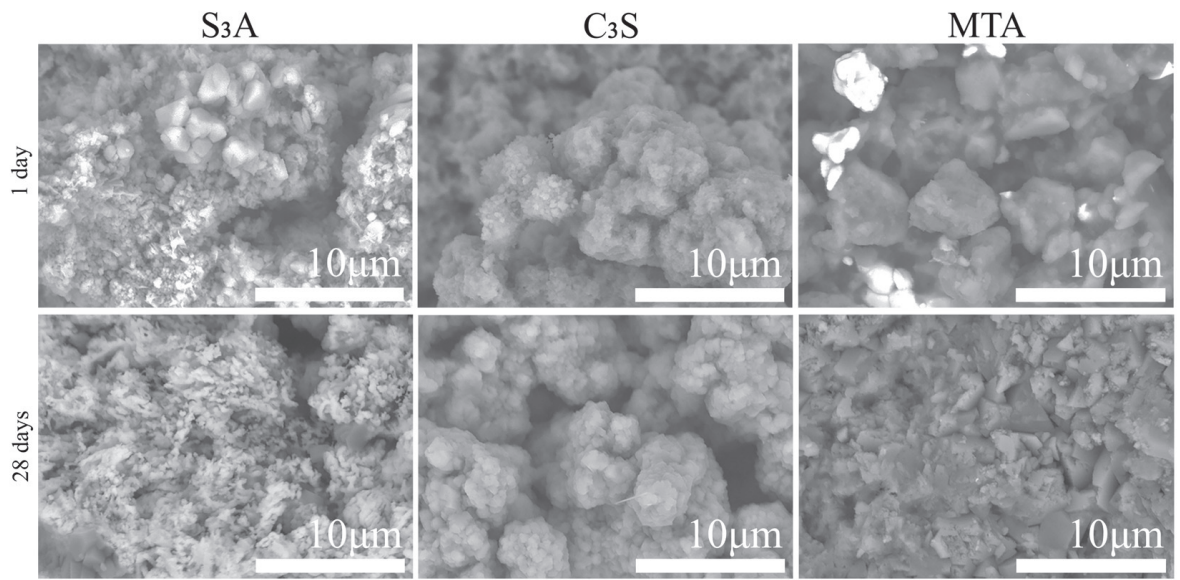

Fig. 3 SEM images of $\mathrm{S}_{3} \mathrm{~A}, \mathrm{C}_{3} \mathrm{~S}$, and MTA cements at $1 \mathrm{~d}$ and $28 \mathrm{~d}$ after kneading.

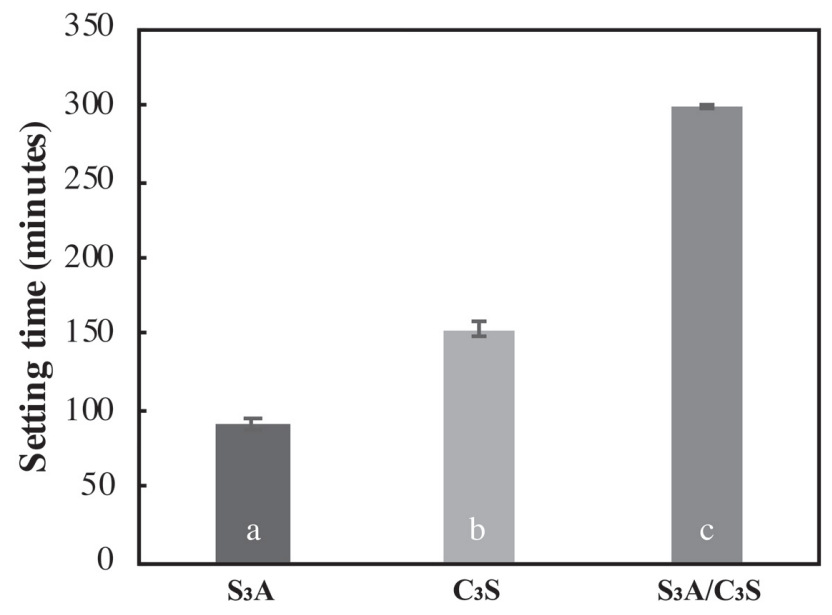

Fig. 4 Setting time analysis. Different letters between each column indicate significant differences $(p<0.05)$.

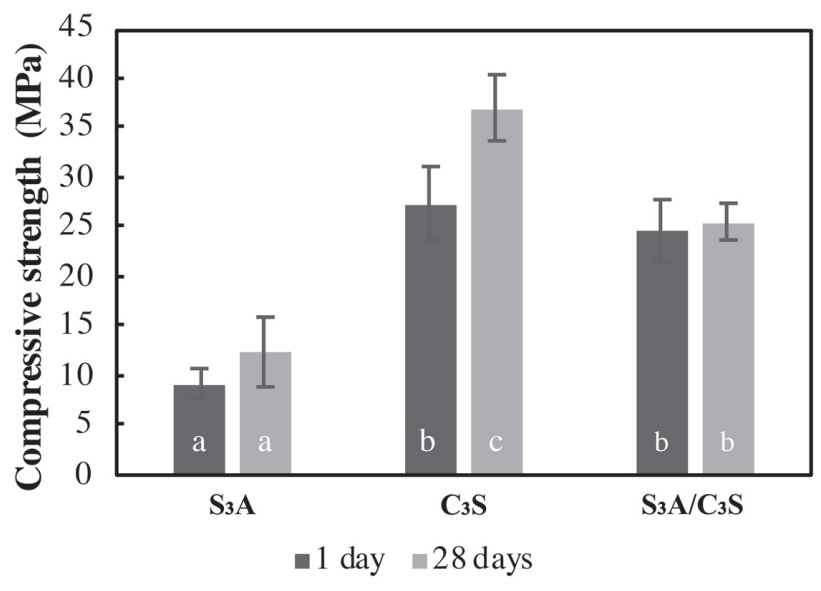

Fig. 5 Compressive strength of $\mathrm{S}_{3} \mathrm{~A}, \mathrm{C}_{3} \mathrm{~S}$, and $\mathrm{S}_{3} \mathrm{~A} / \mathrm{C}_{3} \mathrm{~S}$ cements after $1 \mathrm{~d}$ and $28 \mathrm{~d}$ from cement kneading. Different letters between each column indicate significant differences $(p<0.05)$. 


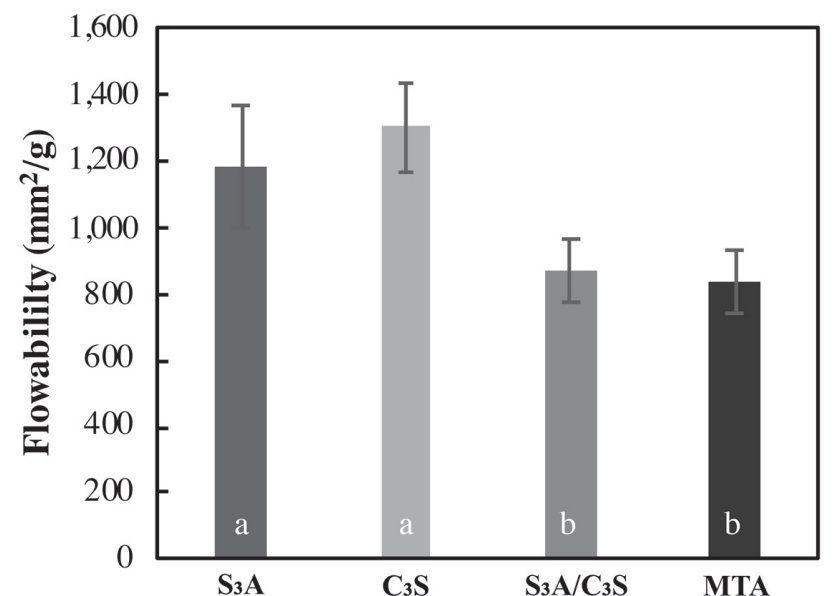

Fig. 6 Relative flowability of cement paste.

Different letters between each column indicate significant differences $(p<0.05)$.

\section{Relative flowability}

The relative flowability (Fig. 6) that was evaluated for the 4 groups $\left(\mathrm{S}_{3} \mathrm{~A}, \mathrm{C}_{3} \mathrm{~S}, \mathrm{~S}_{3} \mathrm{~A} / \mathrm{C}_{3} \mathrm{~S}\right.$ and $\left.\mathrm{MTA}\right)$ showed no significant difference between $\mathrm{S}_{3} \mathrm{~A}$ and $\mathrm{C}_{3} \mathrm{~S}$, as well as between $\mathrm{S}_{3} \mathrm{~A} / \mathrm{C}_{3} \mathrm{~S}$ and MTA. However, both $\mathrm{S}_{3} \mathrm{~A} / \mathrm{C}_{3} \mathrm{~S}$ and MTA had significantly lower flowability than both $\mathrm{S}_{3} \mathrm{~A}$ and $\mathrm{C}_{3} \mathrm{~S}(p<0.001)$.

\section{Radiopacity}

$\mathrm{S}_{3} \mathrm{~A}$ and $\mathrm{S}_{3} \mathrm{~A} / \mathrm{C}_{3} \mathrm{~S}$ mixture achieved the requirement of the $\mathrm{Al}$ thickness of $3 \mathrm{~mm}$, as shown in Fig. 7. There was no significant difference between the radiopacity of $\mathrm{S}_{3} \mathrm{~A}$ and MTA. $\mathrm{S}_{3} \mathrm{~A} / \mathrm{C}_{3} \mathrm{~S}$ mixture showed significantly lower radiopacity than MTA $(p<0.001)$; however, it still attained a $3 \mathrm{~mm} \mathrm{Al}$ thickness.

\section{DISCUSSION}

MTA cement is based on calcium silicate, which has low radiopacity. Therefore, heavy elementoxides (e.g. bismuth oxide) were added as radiopacifiers. Past investigations showed that bismuth oxide is not an inert component, but actively reacts in the hydration mechanism of MTA. This reaction generates a weaker microstructure as compared to hydrated Portland cement, which leads to an increased porosity and a decrease in compressive strength $^{34,35)}$. Considering the tooth discoloration caused by bismuth oxide ${ }^{16,17)}$, an alternative cement component that has enough radiopacity is desirable. In this study, we focused on $\mathrm{S}_{3} \mathrm{~A}$ as the self-setting and radiopaque component for MTA cement.

In this study, $\mathrm{S}_{3} \mathrm{~A}$ could be synthesized under calcination at $1,200^{\circ} \mathrm{C}$ from the hydroxide of strontium and aluminum as a resource. Portland cement clinker is usually calcined at $1,400-1,500^{\circ} \mathrm{C}$. Therefore, $\mathrm{S}_{3} \mathrm{~A}$ would be a good fit in an energy saving process. As shown in Fig. 2 , the particle sizes of $\mathrm{S}_{3} \mathrm{~A}$ were still larger than other cements and their shape was irregular. This caused the
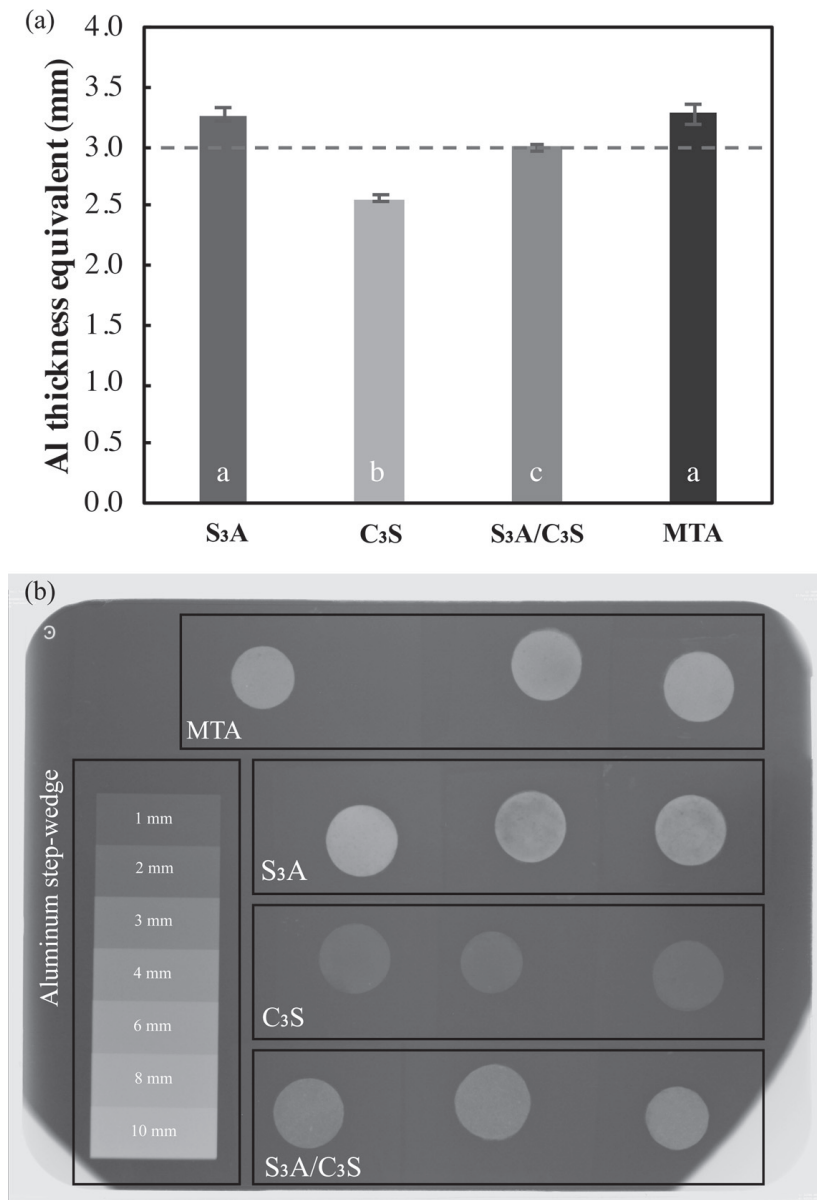

Fig. 7 (a) Radiopacity values of cements presented as $\mathrm{Al}$ thickness equivalent ( $\mathrm{mm}$ ).

The dotted line shows the $3 \mathrm{~mm} \mathrm{Al} \mathrm{thickness}$ from which the cement radiopacity is considered sufficient. Different letters between each column indicate significant differences $(p<0.05)$. (b) Digital radiograph of cements samples and $\mathrm{Al}$ step-wedge.

$\mathrm{S}_{3} \mathrm{~A}$ and $\mathrm{S}_{3} \mathrm{~A} / \mathrm{C}_{3} \mathrm{~S}$ mixture to require a larger $\mathrm{W} / \mathrm{P}$ ratio (0.6) than that of $\mathrm{C}_{3} \mathrm{~S}(0.5)$ and MTA (0.33).

The long setting time is a drawback of $\mathrm{C}_{3} \mathrm{~S}$-based cements. In this study, $\mathrm{S}_{3} \mathrm{~A}$ showed shorter setting time (90.7 min) than $\mathrm{C}_{3} \mathrm{~S}$ (153 min). Generally, it has been well-established that aluminate shows faster hydration than silicate ${ }^{36)}$. Therefore, the shorter setting time of $\mathrm{S}_{3} \mathrm{~A}$ is reasonable. $\mathrm{S}_{3} \mathrm{~A} / \mathrm{C}_{3} \mathrm{~S}$ mixture showed longer setting time (299 $\mathrm{min})$ than that of the other components and also comprised a reported value for ProRoot MTA (261 $\mathrm{min})^{37)}$. Because of this reason, the mismatch of particle size in $\mathrm{S}_{3} \mathrm{~A}$ and $\mathrm{C}_{3} \mathrm{~S}$ could be suggested. If $\mathrm{S}_{3} \mathrm{~A}$ powders had a larger particle size than $\mathrm{C}_{3} \mathrm{~S}$, then the packing efficiency of particles in their mixture would be decreased and the setting reaction would be slower.

Concerning the compressive strength, $\mathrm{S}_{3} \mathrm{~A}$ exhibited a strength that was one-third to that of $\mathrm{C}_{3} \mathrm{~S}$ for one day as well as after $28 \mathrm{~d}$ of maturation. For the $\mathrm{S}_{3} \mathrm{~A} / \mathrm{C}_{3} \mathrm{~S}$ 
mixture, compressive strength after $1 \mathrm{~d}$ was comparable to that of $\mathrm{C}_{3} \mathrm{~S}$. Further, $\mathrm{C}_{3} \mathrm{~S}$ showed significant increase in the compressive strength from 1 to $28 \mathrm{~d}$, whereas both $\mathrm{S}_{3} \mathrm{~A}$ and the $\mathrm{S}_{3} \mathrm{~A} / \mathrm{C}_{3} \mathrm{~S}$ mixture did not show a significant increase. This was a result of the fast hydration reaction of aluminate as described above. The compressive strength of commercial MTA (ProRoot MTA) has been reported as 27.41 and $86.02 \mathrm{MPa}$ after $1 \mathrm{~d}^{38)}$ and $28 \mathrm{~d}^{39)}$ of maturation, respectively. Based on the low compressive strength of $\mathrm{S}_{3} \mathrm{~A}$-based cements, a high W/P ratio and a low packing density of the cement was suggested, which were caused by its large particle size and irregular shape. Thus, considering the extension of the setting time of the $\mathrm{S}_{3} \mathrm{~A} / \mathrm{C}_{3} \mathrm{~S}$ mixture, the improvement in the filling in terms of the shape and size of the particle should be studied in the future.

Relative flowability was chosen as a representative for observing the properties of the cements. In this study, $\mathrm{S}_{3} \mathrm{~A}$ was mixed with higher W/P ratio, which was the reason of its apparently high flowability. Because MTA could be kneaded at almost half the W/P ratio than $\mathrm{S}_{3} \mathrm{~A}$, it contributes toward its high compressive strength.

$\mathrm{S}_{3} \mathrm{~A}$ showed similar radiopacity to the commercial MTA without the addition of a radiopacifier, such as bismuth oxide. Even in the $\mathrm{S}_{3} \mathrm{~A} / \mathrm{C}_{3} \mathrm{~S}$ mixture, if enough radiopacity was achieved, $\mathrm{S}_{3} \mathrm{~A}$ would contribute as the fast hydrated, and radiopaque component of the MTA cement.

Another type of strontium aluminate $\left(\mathrm{SrAl}_{2} \mathrm{O}_{4}\right)$ is popularly used in phosphors. $\mathrm{SrAl}_{2} \mathrm{O}_{4}$ nano-particles have been reported as non-cytotoxic ${ }^{40)}$. Therefore, $\mathrm{S}_{3} \mathrm{~A}$ could be expected to have low cytotoxicity. However, further estimation of cytotoxicity and the biological effects of $\mathrm{S}_{3} \mathrm{~A}$ should be carried out in future studies.

\section{CONCLUSION}

In this study, $\mathrm{S}_{3} \mathrm{~A}$ was synthesized from strontium and aluminum hydroxides by calcination at $1,200^{\circ} \mathrm{C}$. $\mathrm{S}_{3} \mathrm{~A}$ displayed a faster setting time than $\mathrm{C}_{3} \mathrm{~S}$ and MTA cements. Further, $\mathrm{S}_{3} \mathrm{~A}$ showed a similar radiopacity as that of MTA without the addition of a radiopacifier. The radiopacity was high enough for the mixture of $\mathrm{S}_{3} \mathrm{~A}$ to $\mathrm{C}_{3} \mathrm{~S}$, which is a major component of MTA. Therefore, $\mathrm{S}_{3} \mathrm{~A}$ can be suggested as a possible cement component that facilitates a fast setting time and a sufficient radiopacity. Current $\mathrm{S}_{3} \mathrm{~A}$ powders have large particles with irregular shapes. This resulted in lower compressive strength; therefore, these require a high W/P ratio for kneading. Further improvement in the particle shape, size, and distribution of $\mathrm{S}_{3} \mathrm{~A}$ is required. In addition, the bioactive effect for the hard tissue regeneration of strontium derived from $\mathrm{S}_{3} \mathrm{~A}$ should be elucidated in future studies.

\section{CONFLICT OF INTEREST}

The authors declare no conflict of interest.

\section{ACKNOWLEDGMENTS}

This work was supported by a Grant-in Aid from the Japan Society for the Promotion of Science (JSPS No. 16H02688).

\section{REFERENCES}

1) Torabinejad M, Hong CU, McDonald F, Pitt Ford TR. Physical and chemical properties of a new root-end filling material. J Endod 1995; 21: 349-353.

2) Arens DE, Torabinejad M. Repair of furcal perforations with mineral trioxide aggregate: two case reports. Oral Surg Oral Med Oral Pathol Oral Radiol Endod 1996; 82: 84-88.

3) Camilleri J, Montesin FE, Brady K, Sweeney R, Curtis RV, Ford TRP. The constitution of mineral trioxide aggregate. Dent Mater 2005; 21: 297-303.

4) Camilleri J. The chemical composition of mineral trioxide aggregate. J Conserv Dent 2008; 11: 141-143.

5) Torabinejad M, Smith PW, Kettering JD, Pitt Ford TR. Comparative investigation of marginal adaptation of mineral trioxide aggregate and other commonly used root-end filling materials. J Endod 1995; 21: 295-299.

6) Kettering JD, Torabinejad M. Investigation of mutagenicity of mineral trioxide aggregate and other commonly used rootend filling materials. J Endod 1995; 21: 537-539.

7) Sumer M, Muglali M, Bodrumlu E, Guvenc T. Reactions of connective tissue to amalgam, intermediate restorative material, mineral trioxide aggregate, and mineral trioxide aggregate mixed with chlorhexidine. J Endod 2006; 32: 10941096.

8) Torabinejad M, Hong CU, Ford TRP, Kettering JD. Antibacterial effects of some root end filling materials. J Endod 1995; 21: 403-406.

9) Al-Hezaimi K, Al-Shalan TA, Naghshbandi J, Oglesby S, Simon JHS, Rotstein I. Antibacterial effect of two mineral trioxide aggregate (MTA) preparations against Enterococcus faecalis and Streptococcus sanguis in vitro. J Endod 2006; 32: 1053-1056.

10) Faraco IM, Holland R. Response of the pulp of dogs to capping with mineral trioxide aggregate or a calcium hydroxide cement. Dent Traumatol 2001; 17: 163-166.

11) Kuratate M, Yoshiba K, Shigetani $Y$, Yoshiba N, Ohshima H, Okiji T. Immunohistochemical analysis of nestin, osteopontin, and proliferating cells in the reparative process of exposed dental pulp capped with mineral trioxide aggregate. J Endod 2008; 34: 970-974.

12) Gandolfi MG, Taddei P, Tinti A, Prati C. Apatite-forming ability (bioactivity) of ProRoot MTA. Int Endod J 2010; 43: 917-929.

13) Torabinejad M, Chivian N. Clinical applications of mineral trioxide aggregate. J Endod 1999; 25: 197-205.

14) Ber BS, Hatton JF, Stewart GP. Chemical modification of ProRoot MTA to improve handling characteristics and decrease setting time. J Endod 2007; 33: 1231-1234.

15) Antonijevic D, Medigovic I, Zrilic M, Jokic B, Vukovic Z, Todorovic L. The influence of different radiopacifying agents on the radiopacity, compressive strength, setting time, and porosity of Portland cement. Clin Oral Investig 2014; 18: 1597-1604.

16) Marciano MA, Costa RM, Camilleri J, Mondelli RFL, Guimarães BM, Duarte MAH. Assessment of color stability of white mineral trioxide aggregate Angelus and bismuth oxide in contact with tooth structure. J Endod 2014; 40: 12351240.

17) Kang SH, Shin YS, Lee HS, Kim SO, Shin Y, Jung IY, et al. Color changes of teeth after treatment with various mineral trioxide aggregate-based materials: An Ex Vivo Study. J 
Endod 2015; 41: 737-741.

18) Belío-Reyes IA, Bucio L, Cruz-Chavez E. Phase composition of ProRoot mineral trioxide aggregate by X-Ray powder diffraction. J Endod 2009; 35: 875-878.

19) Camilleri J. Characterization and hydration kinetics of tricalcium silicate cement for use as a dental biomaterial. Dent Mater 2011; 27: 836-844.

20) Zhao W, Wang J, Zhai W, Wang Z, Chang J. The self-setting properties and in vitro bioactivity of tricalcium silicate. Biomaterials 2005; 26: 6113-6121.

21) Formosa LM, Mallia B, Camilleri J. The effect of curing conditions on the physical properties of tricalcium silicate cement for use as a dental biomaterial. Int Endod J 2012; 45: 326-336.

22) Dedhiya MG, Young F, Higuchi WI. Mechanism for the retardation of the acid dissolution rate of hydroxyapatite by strontium. J Dent Res 1973; 52: 1097-1109.

23) Featherstone JDB, Shields CP, Khademazad B, Oldershaw MD. Acid reactivity of carbonated apatite with strontium and fluoride substitutions. J Dent Res 1983; 62: 1049-1053.

24) Spets-Happonen S, Luoma H, Seppä L, Räisänen J. The effect of different strontium concentrations on the efficacy of chlorhexidine-fluoride-strontium gel in preventing enamel softening in vitro. Arch Oral Biol 1993; 38: 107-112.

25) Thuy TT, Nakagaki H, Kato K, Hung PA, Inukai J, Tsuboi $\mathrm{S}$, et al. Effect of strontium in combination with fluoride on enamel remineralisation in vitro. Arch Oral Biol 2008; 53: 1017-1022.

26) Uo M, Wada T, Asakura K. Structural analysis of strontium in human teeth treated with surface pre-reacted glass-ionomer filler eluate by using extended X-ray absorption fine structure analysis. Dent Mater J 2017; 36: 214-221.

27) Ogawa A, Wada T, Mori Y, Uo M. Time dependence of multiion absorption into human enamel from surface prereacted glass-ionomer (S-PRG) filler eluate. Dent Mater J 2019; 38: 707-712.

28) Bakhit A, Kawashima N, Hashimoto K, Noda S, Nara K, Kuramoto M, et al. Strontium ranelate promotes odonto-/ osteogenic differentiation/mineralization of dental papillae cells in vitro and mineralized tissue formation of the dental pulp in vivo. Sci Rep 2018; 8: 9224-9210.

29) Shahid S, Hassan U, Billington RW, Hill RG, Anderson P. Glass ionomer cements: effect of strontium substitution on esthetics, radiopacity and fluoride release. Dent Mater 2014; 30: 308-313.

30) Ptáček P, Šoukal F, Opravil T, Bartoníčková E, Zmrzlý M, Novotný R. Synthesis, hydration and thermal stability of hydrates in strontium-aluminate cement. Ceram Int 2014; 40: 9971-9979.

31) International Organization for Standardization. ISO 9917-1. Dentistry -Water-based cements- Part 1: Powder/liquid acid-base cements, 2007.

32) Kang D, Wada T, Uo M, Okiji T. Influence of bentonite addition on the handling and physical properties of tricalcium silicate cement. Asian Pac J Dent 2018; 18: 37-44.

33) International Organization for Standardization. ISO 6786. Dentistry - Root canal sealing materials, 2001.

34) Camilleri J. Hydration mechanisms of mineral trioxide aggregate. Int Endod J 2007; 40: 462-470.

35) Coomaraswamy KS, Lumley PJ, Hofmann MP. Effect of bismuth oxide radioopacifier content on the material properties of an endodontic Portland cement-based (MTAlike) system. J Endod 2007; 33: 295-298.

36) Kohlhaas B. Cement engineers' handbook. Bauverlag GMBH, Wiesbaden and Berlin. p.149-150.

37) Choi Y, Park SJ, Lee SH, Hwang YC, Yu MK, Min KS. Biological effects and washout resistance of a newly developed fast-setting pozzolan cement. J Endod 2013; 39: 467-472.

38) Hwang YC, Kim DH, Hwang IN, Song SJ, Park YJ, Koh JT, et al. Chemical constitution, physical properties, and biocompatibility of experimentally manufactured Portland cement. J Endod 2011; 37: 58-62.

39) Islam I, Kheng Chng H, Jin Yap AU. Comparison of the physical and mechanical properties of MTA and Portland cement. J Endod 2006; 32: 193-197.

40) Montes-Frausto JB, Juarez-Moreno K, Can-Uc B, HirataFlores GA. Synthesis and cytotoxic effects of $\mathrm{SrAl}_{2} \mathrm{O}_{4}$ persistent luminescence nanoparticles co-doped with $\mathrm{Eu}^{2+} /$ $\mathrm{Dy}^{3+}$ ions. Opt Mater Express 2016; 6: 1488-1499. 